\title{
Assessment of the Role and Functions of Human Resources Department in Small and Medium Scale Enterprise Companies in Ile - Ife, Osun
}

\author{
Fatile Ayobami Joshua \\ Department of Human Resource Management, Ife Business School, Ile-Ife, Nigeria
}

Email address:

fatileayobami@gmail.com

\section{To cite this article:}

Fatile Ayobami Joshua. Assessment of the Role and Functions of Human Resources Department in Small and Medium Scale Enterprise Companies in Ile - Ife, Osun. Journal of Human Resource Management. Vol. 7, No. 2, 2019, pp. 32-40. doi: 10.11648/j.jhrm.20190702.11

Received: September 13, 2018; Accepted: October 4, 2018; Published: June 26, 2019

\begin{abstract}
This study was conducted to investigate the role and functions of the Human Resources Department in the various small and medium scale enterprise companies, in Ile-Ife, Osun State, Nigeria. It identified the functions and roles of the Human Resources Department in the Small and Medium Scale Enterprise (SMEs) in Ile-Ife, Osun State, and also examine how these functions affects the workers' efficiency and effectiveness as well as the Organization overall productivity. The reconnaissance survey research design was used for this study. The population of the study consisted of the human resource manager and other employees of all the various small and medium scale enterprise companies, in Ile-Ife. The sample size comprised the Human Resource Manager/Personnel and the Members of staff of the 20 randomly selected companies in Ile-Ife. Four employees were randomly selected from each of the selected companies constituting eighty staff and the twenty heads of the HR department of the companies were purposively selected. Data were collected using structured questionnaire and an interview guide. The questionnaire titled the role and functions of human resources department in small and medium scale enterprise questionnaire" (RFHRDSMEQ) was used to gather information about the role, functions and importance of the human resource department from the employees. The interview guide on role and functions of human resources department in small and medium scale enterprise was issued to the heads of HR department to justify the information gathered from the employees. Data collected were analyzed using descriptive statistics such as simple percentage, charts and tables in the summary and interpretation of the data collected. The study depicted that the larger percentage of the respondents have spent 3-4years in their respective companies. It also revealed that compensation and reward were HR functions that almost all personnel in the selected companies enjoyed because they were available and easily accessible. The study showed that all the functions of the HR department had impact on the effectiveness and efficiency of all the workers. Lastly, it was discovered that the HR department is the most important department in any organization because it deals with human resources which are the most important, valuable and appreciable asset of any organization. In conclusion. Human resource management functions are pivotal to any organisation whether small, medium or large. This is because Human Resource Management is essential to optimal performance of any organization.
\end{abstract}

Keywords: Human Resource Functions, Staff Performance, Effectiveness and Efficiency, Productivity

\section{Introduction}

Managing man is a very challenging issue because man is unequivocally dynamic in nature. People are different in various and diverse manners, such as in mental abilities and behaviours; they differ widely also as a group and are subject to many varied influences. People are also responsive as they feel, think and act therefore they cannot be operated like a machine or shifted and altered like template in a room layout. They therefore need a tactful handing by management personnel that is privilege to have this array of valuable resources.

Human Resource Management is a field that deals with the human components in any organization. It is the process of managing people of an organization with a human approach. In addition, Boxall \& Purcell argued that "HRM includes 
anything and everything associated with the management of employment relationships in the firm." The forgoing definition by Boxall and Purcell indicate that all the elements that are involved in people management which include the process, policies, procedure, practice, etc. are part and parcel of human resource management. Human resources approach to manpower enables the manager to view the people as an important resource. It is the approach through which organization can utilize the manpower not only for the benefits of the organization but also for the growth, development and self-satisfaction of the concerned people. Thus, HRM is a system that focuses on human resources development on one hand and effective management of people on the other hand so that people will enjoy human dignity in their employment. HRM is involved in providing human dignity to the employees taking into account their capacity, potentially, talents, achievement, motivation, skill, commitment, great abilities, and many other components that make up the whole person so that their personalities are recognized as valuable human beings [3]

According to Armstrong, Human Resource Management (HRM) is defined as a strategic and coherent approach to the management of an organization's most valued assets - the people working there who individually and collectively contributes to the achievement of its objectives [1]. From this definition, we can deduce that HRM or simply HR is a function in organizations designed to maximize employee performance in service of their employer's strategic objectives [7]. HR is primarily concerned with how people are managed within organizations, focusing on policies and systems [5]. HR is also concerned with industrial relations, that is, the balancing of organizational practices with regulations arising from collective bargaining and governmental laws [8]. Human Resource Management is an indispensable arm of any sane organisation and is pivotal if it will have global relevance.

The human resource management department is an integral part of any sane organization. They are involved in the development and implementation of human resource management strategies and policies and some or all of the following people management activities: organization development, human resource planning, talent management, knowledge management, recruitment, and selection, learning and development, reward management, employee relations, health and safety. Encyclopedia of Business and Finance has stated that HRM has seven key functionalities. The seven management functions are staffing, performance appraisals, compensation and benefits, training and development, employee and labour relations, safety and health, and human resource research. HR departments and units in organizations are typically responsible for a number of activities, including employee recruitment, training and development, performance appraisal, and rewarding (e.g., managing pay and benefit systems) [14].

The differences in the interpretation of human resource management have created two different schools of thought: soft and hard variants of human resource management [15].
Soft and hard human resource management are also often defined as two main models of human resource management. Soft HRM focuses on employee training, development, commitment and participation. It is used to define HR functions aimed to develop motivation, quality and commitment of employees; hard HRM, on the other hand, concentrates mostly on strategy where human resources are used to achieve organisational goals. It is also associated with cost control and head count strategies, especially in business processes like downsizing, lowering the wages, shortening comfort breaks, etc. [2].

\subsection{Policy Goals of HRM}

The aims highlighted and other definitions of human resource management have been broken down into 12 policy goals:

(1) Managing people as assets that are fundamental to the competitive advantage of the organization

(2) Aligning HRM policies with business policies and corporate strategy

(3) Developing a close fit of HR policies, procedures and systems with one another

(4) Creating a flatter and more flexible organization capable of responding more quickly to change

(5) Encouraging team working and co-operation across internal organizational boundaries

(6) Creating a strong customer-first philosophy throughout the organization

(7) Empowering employees to manage their own selfdevelopment and learning

(8) Developing reward strategies designed to support performance-driven culture

(9) Improving employee involvement through better internal communication

(10)Building employee commitment tom the organization

(11)Increasing line management responsibility of human resource policies

(12)Developing the facilitating role of managers as enablers

The implementation of the above 12 policy give the HR department a distinctive role in any organisation. They all act together to make the department a partner in progress and indispensable to the growth of the organisation and indeed a strong platform of building a talented and resourceful workforce that serve as the competitive edge of any organisation. [4]

There are many advantages that HR provides in an organization some of them include:

(1) The assistance it provides in recruiting staff and in training employee. The HR department is mostly responsible to develop the systematic plan according to which they hire the staff, depending on the financial strength of the organization and helping organization to build a professional work team.

(2) HR provides consultancy. HR is very effective in an organization to settle down any managerial disagreement or employee problem in a professional 
and proficient manner.

(3) One more advantage of HR is that the HR system comprises of highly dedicated professionals who have the ability to develop new plan and implement marketing strategies that would bring more business and capital to the organization.

(4) HR helps the business and commerce to make public relations and build a proper referral system. It is very necessary that the business develops an association with other businesses in the market so it could propel its earning through collaboration with other business sectors. The HR department arranges seminars, business meetings and official gathering for the company so that it gets acquainted with the market and other businesses.

These advantages therefore clearly illustrate how important the HR is for an organization. Whether the business is small or it's a big budget industry, building and maintaining a high profile HR system is very necessary if the business wants to avoid disputes and problems in the longer run.

\subsection{Functions of Human Resource Department}

An efficiently run human resources department can provide an organization with structure and the ability to meet business goals through managing the company's most valuable assets, its employees. In small businesses without a dedicated HR department, it's possible to achieve the same level of efficiency and workforce management through outsourcing HR functions or joining a professional employer organization. There are several HR disciplines, or areas, but HR practitioners in each discipline may perform more than one of the more than six essential functions.

\subsubsection{Recruitment and Selection}

The success of recruiters and employment specialists generally is measured by the number of positions they fill and the time it takes to fill those positions. Recruiters who work in-house as opposed to companies that provide recruiting and staffing services- play a key role in advertising job postings, source candidates, screen applicants, conduct preliminary interviews and coordinate hiring efforts with managers responsible for making the final selection of candidates.

\subsubsection{Health and Safety}

Workplace safety is an important factor. Under the occupational safety and Health Act of 1970, employers have an obligation to provide a safe working environment for employees. One of the main functions is to support workplace safety training and maintain federally mandated logs for workplace injury and fatality reporting. In addition, HR safety and risk specialists often work closely with HR benefits specialists to manage the company's workers' compensation issues.

\subsubsection{Employee Relations}

In a unionized work environment, the employee and labour relations functions of H.R may be combined and handled by one specialist or be entirely separate functions managed by two HR specialists with specific expertise in each area. Employee relations is the HR discipline concerned with strengthening the employer -employee relationship through measuring job satisfaction, employee engagement and resolving workplace conflict. Labour relation functions may include developing management response to union organizing campaigns, negotiating collective bargaining agreements and rendering interpretations of labour union contract issues.

\subsubsection{Compensation and Benefits}

Like employee and labour relations, the compensation and benefits functions of H.R often can be handled by one HR specialist with dual expertise. On the compensation side, the HR functions include setting compensation structures and evaluating competitive pay practices. Payroll can be a component of the compensation and benefits section of HR; however, in many cases, employers outsource such administrative functions as payroll.

\subsubsection{Compliance}

Compliance with labour and employment laws is a critical HR function. Non-compliance can result in work place complaints based on unfair employment practices, unsafe working conditions and general dissatisfaction with working conditions that can affect productivity and ultimately, profitability.

\subsubsection{Training and Development}

Employers must provide employees with the tools necessary for their success which in many cases, means giving new employees extensive orientation training to help them transition into a new organizational culture. Many HR departments also provide leadership training and professional development. Leadership training may be required of newly hired and promoted supervisors and managers on topics such as performance management and however to handle employee relations matters at the department level. Professional development opportunities are for employees looking for promotional opportunities or employees who want to achieve personal goals such as finishing a college degree.

Other functions of Human Resource Management include:

(1) Talent Management: It is the use of an integrated set of activities to ensure that the organization attracts, retains, motivates and develops the talented people it needs now and in future

(2) Encouraging team spirit among workers by tolerating individual differences

(3) Crisis management and conflict resolution

(4) To exercise leadership skills that depict competencies, proper planning, critical thinking and ability to motivate the workers

(5) Create a strategic means of communication

"HR Functions and the entire system of HR as a whole are distinctive approach to employment management which seeks to achieve competitive advantage through the strategic 
deployment of a highly committed and capable workforce, using an array of cultural, structural and personnel techniques." [16].

\subsection{Effectiveness and Efficiency}

'Effectiveness' basically means to produce a result that is wanted or desired. It has the sense of accomplishing something, such as a purpose or a task, and accomplishing it well or to completion. The meaning can be seen in the example, 'She was effective in persuading her boss to give her the day off'. Or the example applying the word to an inanimate object, 'The cleaner was effective in removing the stain'. When something is done 'effectively', it is done right or correctly. 'Adequate', meaning acceptable or meeting a need, is a good synonym for effective.

'Efficient' has the meaning of doing something in the best possible manner. It means to produce the desired results or accomplishments while doing it in the best way. Usually, it specifically applies to not wasting time or money in doing something. This can be illustrated with the sentence, He is an efficient worker because he gets the job done quickly and correctly. Efficiency also can be linked to 'productivity', which means to work hard and produce results. By being an effective worker, you are also a productive worker.

Improving the efficiency of HR administration will reduce manual processing, improve consistency and compliance, make fixed costs variable and reduce capital investments in HR. Efficient human resource management will ensure the effective and efficient performance of each personnel in the organisation and this will eventually make the overall costs for the entire organisation reduce. Minimisation of cost and maximisation of profit is one of the means of assessing organisational performance and productivity and these is ultimately the product of effective and efficient planning and implementation of human resource functions in an organisation.

Economy degradation of recent times has emphasized the significance of reasons why organizations should operate in efficient manners. As a result of the rapid changes in the global economy, an organization's efficiency is more often than before impacted by the effectiveness of its human resource management. This is why the most effective and successful companies of today find ways to motivate, train, compensate, and challenge their employees. This is absolutely important for all companies, whether they are manufacturing or service companies, large or small, domestic or international.

\subsection{Small and Medium Scale Enterprise}

All business organisations can be classified into two major groups according to their sizes. First and foremost are Small and medium business organisations and secondly, big or large business organisations. Small and medium scale enterprise include Sole proprietorship and Partnership. The big businesses include Limited Liabilities Companies, Public Corporations, and Cooperative Societies. Osuala posited that small scale enterprise are the ones in the categories of 5 or 10 workers to between $20-50$ workers. He further described a small business enterprise in Nigeria context as a business owned, managed and controlled by a sole proprietor, or partners of about two persons, has a total assets of less than four million naira, and a relatively small share of market and does not have more than fifty employees [11]. Olagunju stated that the ownership, restriction of the market to the immediate environment of the business, total capital investment and the rate of turn-over, are the major and probably the acceptable indices for measuring the smallness or bigness of aby business [10. The city of Ile-Ife in Osun State which is located at the Western part of Nigeria is dominated with small scale enterprise and most of them do not really have a specialised human resource department. However, the manager, managing director or CEO of most of these organisations carry out the human resource functions in those organisations. This is one of the vital pointer to the fact that the organisations in this environment are predominantly small scale businesses.

However, human resource management functions are essential to any organization, whether the organization is big or small. Great emphases should be laid on implementing an effective HR system in an organization.

\subsection{Statement of the Research}

Managing man in any organizational is not an easy task as every man is unique in character, behaviour, physical strength and attitude. There is a cogent need for managing them for effective and efficient performance of the individual staff as well as to enhance the attainment of the overall organizational objectives. Meanwhile, when human resource comes to the mind of an average man, what he thinks is "hiring" and "firing", because many people do not realise that human resource management is more encompassing than that. As a result of this, small and medium scale enterprises in Nigeria seems not to really have a good grasps of the importance of human resource professionalism and its relevance to organizational development. Hence, this research therefore was conducted on the functions of Human Resource Management in small and medium scale enterprise in Ile-Ife, Osun state.

\subsection{Purpose of the Study}

The aim of the study was to

(1) To identify the functions or roles of the Human Resources Department in the various Small and Medium Scale Enterprise (SMEs) in Ile-Ife, Osun State, Nigeria.

(2) To examine how these functions affects the workers performance efficiency and effectiveness as well as the Organization overall productivity.

\subsection{Research Questions}

The following research questions were raised to guide the study; 
(1) What are the functions of human resource personnel in Small and Medium Scale Enterprises (SMEs)?

(2) How does human resources functions affect workers performance [effectiveness and efficiency] and productivity in the Organization

\section{Methodology}

\subsection{Research Design}

The reconnaissance survey research design was used for this study. This research design is an exploratory survey or examination which helps in seeking out information about a place. The design was deemed appropriate for the study because the research was aimed at finding out the detailed information of the functions, roles and importance of the HR departments in the selected companies in Ile-Ife.

Interview is good for gathering immediate and first-hand information from the respondent. Questionnaires are a good way to obtain information from a large number of people and/or people who may not have the time to attend to an interview. They enable people to take their time, think about it and come back to the questionnaire later. Participants can state their views or feelings privately without worrying about the possible reaction of the researcher.

\subsection{Population of the Study}

The population of the study consisted all the human resource managers and other employees of the twenty selected companies in Ile-Ife.

\subsection{Sampling Technique}

Simple random and purposively sampling techniques was adopted for this study. The sample size was calculated based on the number of staff available in the companies since most of them are small sized company. Four employees were randomly selected from each of the selected companies making a total of eighty staff and the twenty heads of the HR department of all the twenty companies were purposively selected.

\subsection{Research Instrument}

The basic research instrument used is a structured questionnaire and an interview guide. The questionnaire titled the role and functions of human resources department in small and medium scale enterprise questionnaire" (RFHRDSMEQ) was used to gather information about the role, functions and importance of the human resource department from the employees. This questionnaire for the employees was designed using the likert-type scale. The interview guide on role and functions of human resources department in small and medium scale enterprise was issued to the heads of HR department to justify the information gathered from the employees.

\subsection{Method of Data Collection}

The instrument was administered to the respondents personally and with the help of two research assistants after taking permission from the appropriate authorities of all the companies that were used. The questionnaire was given to the staff to fill and asked for the appropriate time to come back for it. This made it possible for the researcher to retrieved ninety-five copies out of the one hundred questionnaire that were distributed after given the respondents enough time to attend appropriately to the instrument. The interview was also conducted in person with the head of each HR department of the twenty SMEs.

\subsection{Method of Data Analysis}

The information gathered was analyzed using descriptive statistics such as simple percentage, charts and tables in the summary and interpretation of the data collected.

\section{Results}

Table 1. Showing the length of Service of Respondents.

\begin{tabular}{lll}
\hline Length of Service & Frequency & Percentage \\
\hline 1-2 years & 30 & 31.5 \\
3-4 years & 41 & 43.3 \\
5-6 years & 24 & 25.2 \\
7 years and above & - & - \\
Total & 95 & 100 \\
\hline
\end{tabular}

Source: Field work, 2017

Table 1 above revealed that $31.5 \%$ of the respondents had spent 1-2 years in their respective job while $43.3 \%$ of the respondents had spent $3-4,25.2 \%$ had spent 5-6 years and nobody had spent 7 years or above in all the organisations that were studied. The table above depicted that the large percentage of the respondents had spent 3-4years in their respective companies

Research Question 1: What are the functions of human resource personnel in Small and Medium Scale Enterprises?

Table 2. Availability and awareness of functions of Human Resource department in your Organization.

\begin{tabular}{|c|c|c|c|c|c|}
\hline \multirow{2}{*}{ H R Functions } & Strongly Agree & Agree & Disagree & Strongly Disagree & Total \\
\hline & Fr & Fr & Fr & Fr & \\
\hline Procurement Function & $20(21 \%)$ & $40(42 \%)$ & $35(36.8 \%)$ & - & $95(100 \%)$ \\
\hline Recruitment and selection & $60(63 \%)$ & $27(28.4 \%)$ & $8(8.4 \%)$ & - & $95(100 \%)$ \\
\hline Training and Development & $36(37.8 \%)$ & $40(42.2 \%)$ & $8(8.4 \%)$ & $11(11.6 \%)$ & $95(100 \%)$ \\
\hline Career Development & $20(21 \%)$ & $36(37.8 \%)$ & $31(32.6 \%)$ & $8(8.4 \%)$ & $95(100 \%)$ \\
\hline Performance Management & $46(48.3 \%)$ & $27(28.4 \%)$ & $10(10.5 \%)$ & $12(12.6 \%)$ & $95(100 \%)$ \\
\hline Compensation and reward & $64(67 \%)$ & $23(24.6 \%)$ & $8(8.4 \%)$ & - & $95(100 \%)$ \\
\hline
\end{tabular}




\begin{tabular}{llllll}
\hline \multirow{2}{*}{ H R Functions } & Strongly Agree & Agree & Disagree & Strongly Disagree & Total \\
\cline { 2 - 6 } & Fr & Fr & Fr & Fr & \\
\hline Health and Safety & $30(31.5 \%)$ & $41(43.1 \%)$ & $9(9.5 \%)$ & 15 & $95(100 \%)$ \\
Compliance & $40(42 \%)$ & $23(24.2 \%)$ & $18(18.9 \%)$ & 14 & $95(100 \%)$ \\
\hline
\end{tabular}

Source: Field work, 2017

The above table showed that the functions of human resource department were readily available in the companies and all members of the staff of the selected companies were aware of these functions of the Human Resources department in their respective organization. It can be concluded from the above table that compensation and reward are the functions of the human resource department that almost all of the personnel in all the companies that were studied claimed to enjoy because they available and easily accessible to them. However, career development is a human resource function that is not really available nor accessible by staff in the organisations that were studied

Research Question 2: How does human resources functions affect workers performance [effectiveness and efficiency] and productivity in the Organization?

Table 3. The impact of human resource functions on staff performance and productivity.

\begin{tabular}{|c|c|c|c|c|c|}
\hline Items & $\begin{array}{l}\text { Strongly } \\
\text { Agree }\end{array}$ & Agree & Disagree & $\begin{array}{l}\text { Strongly } \\
\text { Disagree }\end{array}$ & Total \\
\hline $\begin{array}{l}\text { The HR department take proper stock of the personnel need and } \\
\text { implement the information gotten for effective and efficient } \\
\text { recruitment purposes }\end{array}$ & $42(44.1 \%)$ & $34(35.7 \%)$ & $14(14.7 \%)$ & $5(5.5 \%)$ & $95(100 \%)$ \\
\hline $\begin{array}{l}\text { The selection process of this organization enhance the staff } \\
\text { performance and productivity }\end{array}$ & $60(63 \%)$ & $18(18.9 \%)$ & $8(8.5 \%)$ & $9(9.6 \%)$ & $95(100 \%)$ \\
\hline $\begin{array}{l}\text { As a new employee of the company, I was properly brief and train to } \\
\text { effectively discharge my duties here }\end{array}$ & $36(37.8 \%)$ & $56(58.8 \%)$ & $3(3.4 \%)$ & $-(-\%)$ & $95(100 \%)$ \\
\hline $\begin{array}{l}\text { Staff performances managed in such a way that positively impact the } \\
\text { organisation's overall objectives }\end{array}$ & $46(48.3 \%)$ & $31(32.7 \%)$ & $12(12.6 \%)$ & $6(6.4 \%)$ & $95(100 \%)$ \\
\hline $\begin{array}{l}\text { The Members of the Staff are given opportunity to develop } \\
\text { themselves in line with their duties here }\end{array}$ & $47(49.6 \%)$ & $48(50.4 \%)$ & $-(-\%)$ & $-(-\%)$ & $95(100 \%)$ \\
\hline $\begin{array}{l}\text { Compensation and reward for each worker is based on the } \\
\text { individual's performance level on the job }\end{array}$ & $16(16.8 \%)$ & $63(66.4 \%)$ & $8(8.4 \%)$ & $8(8.4 \%)$ & $95(100 \%)$ \\
\hline $\begin{array}{l}\text { I'm pleased and motivated by the way employee relations issues are } \\
\text { been handled in this organisation }\end{array}$ & $42(44.1 \%)$ & $44(46.2 \%)$ & $7(7.4 \%)$ & $2(2.3 \%)$ & $95(100 \%)$ \\
\hline $\begin{array}{l}\text { The HR department focuses on and provide a healthy and safe } \\
\text { environment conducive to work }\end{array}$ & $30(31.5 \%)$ & $31(32.7 \%)$ & $9(9.5 \%)$ & $25(26.3 \%)$ & $95(100 \%)$ \\
\hline $\begin{array}{l}\text { The personnel department complies with the rules of the labour law } \\
\text { in this organisation }\end{array}$ & $40(42.2 \%)$ & $42(44.1 \%)$ & $8(8.4 \%)$ & $5(5.3 \%)$ & $95(100 \%)$ \\
\hline
\end{tabular}

Source: Field work, 2017

It can be inferred that the functions of the human resource department in the selected companies had definite effect on staff performance in terms of the effectiveness and efficiency of the staff and also on their productivity. As observed from the table above, all the functions of the human resource management were said to have impacted the effectiveness and efficiency of the workers in all the companies that were studied.

Most members of staff have directly or indirectly been impacted by the human resource personnel/department of the company. They answered the questionnaire and agree that the Human Resource department functions have effectively and efficiently impacted on their performance and the productivity of their company.

Table 4. Interview Response.

\begin{tabular}{|c|c|c|}
\hline $\mathbf{S} / \mathbf{N}$ & Questions & Answers \\
\hline 1 & $\begin{array}{l}\text { What role/function do you play as the HR in your } \\
\text { organisation? }\end{array}$ & $\begin{array}{l}\text { a. Manage the human resources } \\
\text { b. Responsible for learning and development of staff } \\
\text { c. Training of staff } \\
\text { d. Increasing productivity of staff } \\
\text { e. Communicates between the employees and the management } \\
\text { f. Talent retention and } \\
\text { g. Talent sourcing and recruitment }\end{array}$ \\
\hline 3 & $\begin{array}{l}\text { From the roles you play here, how do you think } \\
\text { these roles affect the effectiveness or productivity } \\
\text { of other employees in the company? }\end{array}$ & $\begin{array}{l}\text { Employee engagement has been on the high rise } \\
\text { The employee have been trained, mentored, }\end{array}$ \\
\hline 4 & $\begin{array}{l}\text { Would you advice the company to improve the } \\
\text { human resource department? }\end{array}$ & $\begin{array}{l}\text { Almost all of them stated that every company needs an HR- based on the size of the firm. } \\
\text { Advice would be the company make plans and take steps to improve the HR department, }\end{array}$ \\
\hline
\end{tabular}




\begin{tabular}{lll}
\hline S/N & Questions & Answers \\
\hline & $\begin{array}{l}\text { If you were asked to counsel someone who wants } \\
\text { to set up an organization on the importance of } \\
\text { having a HRM in his/her organization, what advice } \\
\text { would you give? }\end{array}$ & $\begin{array}{l}\text { enlarge it to help the job get done easier and faster. } \\
\text { The response of all of them was tilled towards taking care of the people in your } \\
\text { organization is taking care of your business. There should be focus on making the people } \\
\text { in an organization better. }\end{array}$ \\
$\begin{array}{l}\text { Would you advice other organizations or companies } \\
\text { who do not have HRM to employ an HR? }\end{array}$ & Yes, if there is capacity to do that. \\
\hline
\end{tabular}

Source: Field work, 2017

Table 4 above showed the response from the interview carried out with the HR personnel of the selected companies. From the table above, it can be summarized that the HR department is the most important department in any organization because it deals with human resources which is the most important, valuable and appreciable asset of any organization.

\section{Findings}

It can be deduced from table 1 above that the large percentage of the respondents had spent 3-4years in their respective companies. Small and medium scale organisations most often have short life span and in some cases where they are in existence for longer period, they tend to remain in a medium size. The nature and the composition of the companies that were studied affected the number of years an employee can spend with them. The majority of the staff in this companies had not spent more than 4 years.

The study revealed that there were different kinds of human resource management functions in the SMEs in IleIfe. Okpara and Pamela examined the extent to which organizations in Nigeria use various functions and perceived challenges and prospect of these functions. Data were collected from 253 managers in 12 selected companies in 10 cities. Their findings revealed that human resource management functions, such as training, recruitment, compensation, performance appraisal and reward system are available and accessible in those companies. [12]

It also showed that the employees of the business units that were studied have a great level of awareness of these functions in their respective organisations. It can be concluded from the above table that career development is a human resource function that was not really available nor accessible by staff in the organizations that were studied. However, compensation and reward were functions of the human resource that almost all of the personnel in all the companies that were studied claimed to enjoy because it's available and easily accessible to them. This is because this functions is one of the most important function that the human resource manager or department does in every organisation. Incentives are usually in monetary rewards forms or other types of incentive-based compensation which are stock option, share ownership (partnership) and additional benefit like bonuses and rewards that are usually given to improve their performance [6].

The human resource functions in each of the organisations had a significant effect on the effectiveness and efficiency of the personnel in the studied enterprise. As observed from the table above, all the functions of the human resource management were said to have impacted the effectiveness and efficiency of the workers in all the companies that were researched into. Human resource functions are the levers or mechanisms through which employee skills can be developed" [13]. Human resource functions are the primary means by which firms can influence and shape the skills, attitudes, and behaviour of individuals to do their work and thus achieve organizational goals. Human resource functions are designed to improve the knowledge, skills and abilities of employees; boost their motivation, minimize or eliminate loitering on the job and enhance the retention of valuable employees; boost their motivation, minimize or eliminate loitering on the job: and enhance the retentions of valuable employees. Those functions includes employee recruitment and selection procedures: incentive compensation and performance management policies, extensive employee training, participation and involvement in decision-making.

From the table above, it can be summarized that the HR department is the most important department in any organization because it dealt with human resources which are the most important, valuable and appreciable asset of any organization. It can also be concluded that issues like tribalism, AIDs, training and development and corruption are some of the challenges facing human resource management in the companies selected in Ile-Ife, Nigeria.

\section{Conclusions}

The main objective of this study was to identify and assess the role and functions of human resources department in small and medium scale enterprise companies in Ile - Ife, Osun. Overall, the result of this study provides evidence in support of the availability and accessibility of the HR functions by the personnel of the selected organisations. In this study the influence of HR practices was seen on employees' effectiveness and efficiency in conjunction with organization's performance in small and medium scale enterprise companies in Ile - Ife, Osun. A sample of 100 staff was taken from different organisations. Data was gathered through questionnaires and interview guide. The responses to the questionnaire were analyzed using descriptive techniques.

Human resource management functions are pivotal to any organisation whether small, medium or large. The HR department is core in any sane organization. People are central and are to be considered assets if the organization is to achieve global impacts. The success of any organization is 
greatly attached to their ability to maximally utilize their workforce. This is because Human Resource Management is essential to optimal performance of any organization and productivity.

\section{Recommendations}

Though from the observation, the organizational staff size with one Human Resource Personnel/Manager was believed to be optimum for the company for now, but all the staff members believe there is need for improvement in the HR department
Small and Medium scale Enterprises in Nigeria have not paid detailed attention to the importance of Human Resource Management in their organizations as they ought to. This may be due to lack of drive for expansion, poor consultation and orientation. For economic and global impacts to be attainable, informed individuals should create awareness about the importance of Human Resource Management in organizations. On the part of the organisations, they can consult H.R firms for more orientation and outsource to them for a stronger organizational structure and increased productivity.

\section{Appendix}

\section{Appendix 1}

Department of Human Resource Management

Ife Business School.

Role and Functions of Human Resources Department in Small and Medium Scale Enterprise Questionnaire” (RFHRDSMEQ) is designed to elicit information on the roles, functions and importance of the human resource department in SMEs in Ile-Ife. The information given will be kept confidential.

Thank you.

Fatile Ayobami

SECTION A: Demographic Information

(1) Name of the organisation:

(2) Age
$25-34()$
$55 \&$ above ( )
Length of Service
1 - 2 years ( )
3 - 4 years ( )
5 - 6 years ( )
7 years and above ( )

SECTION B: Awareness of and the Importance of human resource departments in SMES

Instruction:

Please rate how strongly you agree or disagree with the following statement listed below by ticking the appropriate options. Please your sincere opinion is of high importance

\begin{tabular}{|c|c|c|c|c|c|}
\hline $\mathbf{S} / \mathbf{N}$ & Questions & Strongly Agree & Agree & Disagree & Strongly Disagree \\
\hline & Procurement Function & & & & \\
\hline & Recruitment and selection & & & & \\
\hline & Training and Development & & & & \\
\hline & Career Development & & & & \\
\hline & Performance Management & & & & \\
\hline & Compensation and reward & & & & \\
\hline & Employee Relations & & & & \\
\hline & Health and Safety & & & & \\
\hline & Compliance & & & & \\
\hline
\end{tabular}

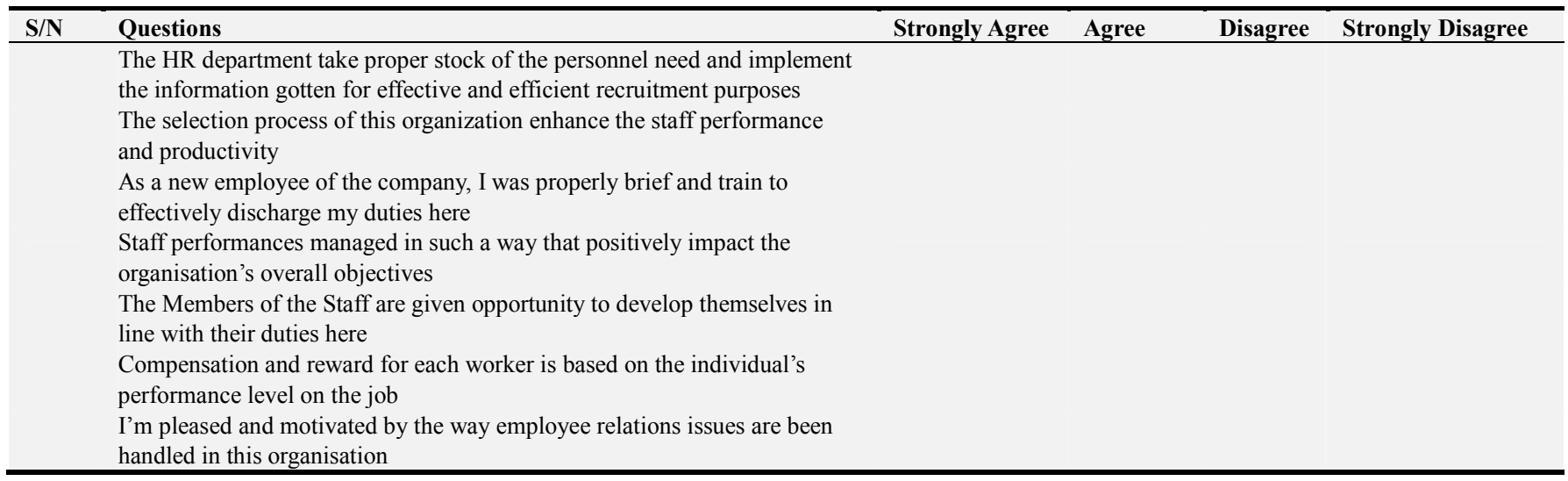




\begin{tabular}{|c|c|c|c|c|c|}
\hline $\mathbf{S} / \mathbf{N}$ & Questions & Strongly Agree & Agree & Disagree & Strongly Disagree \\
\hline & $\begin{array}{l}\text { The HR department focuses on and provide a healthy and safe environment } \\
\text { conducive to work }\end{array}$ & & & & \\
\hline & $\begin{array}{l}\text { The personnel department complies with the rules of the labour law in this } \\
\text { organisation }\end{array}$ & & & & \\
\hline
\end{tabular}

\section{Appendix 2}

\section{DEPARTMENT OF HUMAN RESOURCE MANAGEMENT \\ IFE BUSINESS SCHOOL. \\ INTERVIEW GUIDE}

This interview guide aims to gather information on the Role and Functions of human Resources Department in SMEs in Ile - Ife, Osun State, Nigeria. Please kindly attend these questions. All information provided will be treated with strict confidentiality and will be used for academic purpose only.

Thank You.

Fatile Ayobami.

(1) How long have you been working as a Human Resource Manager in this organization?

(2) What role/function do you play as a Human Resource Manager?

(3) From the role (s) you play in this Company, how do you think these roles affect the effectiveness or productivity of the employees here?

(4) Would you advice the company to improve the human resource department for more effectiveness or just forget everything human resource?

(5) If asked to counsel someone who wants to set up an organization on the importance of Human Resource Management in his/her organization, what advice would you give?

(6) Would you advice other organizations or companies who do not have human Resource personnel to set up HRM departments in their organization (s)?

\section{References}

[1] Armstrong, M. (2010). A Handbook of Human Resource Management Practice. 10th ed. Kogan Page: London.

[2] Beardwell, J. and Claydon, T. (2007). Human Resource Management: A Contemporary Approach, Prentice Hall, England, UK.

[3] Boxall, P. \& Purcell, J. (2003). Strategy and Human Resource Management. Basingstoke and New York: Palgrave Macmillan.

[4] Caldwell (2014). Policy Goals of Human Resource Management, Saturday, August 16, 2014.

[5] Collings \& G. Wood (Eds.), Human resource management: A critical approach (pp. 1-16). London: Routledge.

[6] Ichniowski, C., K. Shaw and G. Prennushi, (1997). The Effects of Human Resource Management Practices on Productivity: A Study of Steel Finishing Lines. The American Economic Review, 87 (3): 291-313.

[7] Johnason, P. (2009). HRM in changing organizational contexts. In D. G. Collings \& G. Wood (Eds.), Human resource management: A critical approach (pp. 19-37). London: Routledge.

[8] Klerck, G. (2009). Industrial relations and human resource management. In D. G. Collings \& G. Wood (Eds.), Human

resource management: A critical approach (pp. 238-259). London: Routledge.

[9] Okpara, J. O and Wynn, P. (2008), "Human Resource Management Practices in a Transition Economy," Management Research News, Vol. 31, No. 1.

[10] Olagunju Y. A. (2004) Enterpreneurship and Small Scale Business Enterprises. University Press Plc, Ibadan.

[11] Osuala, E. C. (2004) Principles and Practices of Small Business Management in Nigeria. Cheston Books.

[12] Okpara, J. O and Wynn, P. (2008), "Human Resource Management Practices in a Transition Economy," Management Research News, Vol. 31, No. 1.

[13] Park, H. J., Mitsuhashi. H., Fey, C. F., and Bjorkman, I. (2003), The effect of Human Resource Management Practices on Japanese MNC subsidiary performance: A Practical Mediating Model, International Journal of Human Resource Management, Vol. 14, No. 8.

[14] Paauwe, J., \& Boon, C. (2009). Strategic HRM: A critical review. In D. G. Collings \& G. Wood (Eds.), Human resource management: A critical approach (pp. 38-54). London: Routledge.

[15] Storey, J. (1992) Development in the Management of Human Resources: An Analytical Review, Blackwell, UK.

[16] Storey, J., (1995): Human Resources Management: A critical text, Routledge London. 